\title{
Histopathological Diagnosis Patterns of Oro-Facial Tumours: A Ten-Year Survey
}

\section{Etetafia MO*}

Department of Oral Maxillofacial Surgery, Delta State University Teaching Hospital, Nigeria

*Corresponding author: Etetafia Okiemute Mabel, Department of Oral Maxillofacial Surgery, Delta State University Teaching Hospital, Oghara, Delta, Nigeria, Tel: +2348023161800; Email: etetmabelo2000@yahoo.com

\section{Research Article}

Volume 5 Issue 2

Received Date: March 16, 2020

Published Date: April 01, 2020

DOI: $10.23880 /$ oajds- 16000246

\section{Abstract}

Background: Facial tumour is a disease condition which arises as a result of unchecked ratio of cell production to cell death among the cells constituting the face such that cell production rate surpasses cell death. This disease condition accounts for about $95 \%$ of the causes of face deformation followed by birth deformity. The aim of this study was to evaluate the histological diagnosis patterns of facial tumour seen at Teem Dental Centre Warri, Delta State. The distribution of facial tumour patterns in relation to various age groups and gender was observed.

Methods: This study was conducted in the histopathological unit of Teem Dental Centre over a period of 10 years. The data were obtained from the medical records of patients seen at the centre within the stated period. Data collected included the age, sex, clinical features of presenting tumours and the histopathological reports of the cases seen either on incisional or excisional basis. Data were analyzed using Social Statistical Package for Social Science version 23 and were depicted in tabular formats.

Results: Patients in the study were aged 5-80 years. The predominant histological pattern of facial tumour was ameloblastoma $9(14.5 \%)$ with the next being cement-ossifying fibroma and Acute and chronic suppurative inflammation having an incidence of $n=6(9.7 \%)$ each. From the study, it was observed that females $35(56.5 \%)$ had a higher prevalence level than their male counterparts $27(43.5 \%)$

Conclusion: The histopathological assessment of the facial tumours showed ameloblastoma to be the commonest pattern with a tendency to more females than males.

Keywords: Facial tumour; Histopathological diagnosis, pattern; Teem Dental

Abbreviations: SPSS: Statistical Package for Social Sciences.

\section{Introduction}

Facial tumour, a disease with an unknown etiology results in abnormal production of cells in the cellular structures of the face and affecting mostly the lower parts of the face, is believed to be responsible for a certain percentage of death globally [1]. Studies have shown the epidemiology of this condition to vary between developed and developing countries as a result of prevalence rate of immunological deficiencies caused by Human Immunodeficiency/Acquired Immunodeficiency Syndrome and Ebsten-Barr Virus [2]. Facial tumour, like all tumours present in two forms, benign tumour and malignant tumour [1]. The histological picture of each tumour depends largely on the cell of origin and the nature of the tumour. While benign tumours are generally painless, slow growing, and do not usually metastasize, malignant tumours are usually fast in growth rate, may be painful and metastasize to other body areas. Histology reports from incisional and excisional biopsies of tumours 


\section{Open Access Journal of Dental Sciences}

differentiate between benign and malignant ones. The knowledge derived from the histological pattern helps in planning for appropriate management. Common features of some tumours are hereby indicated. Chronic sialadenitis a benign form of facial tumour arises from the formation of fibrous mass as a result of an acute infection affecting the salivary gland (acini, ducts as well as lobules) with its causative agent being a bacteria named staphylococuss aureus [3]. Certain risk factors such as dehydration as well as poor oral hygiene have shown to have an influence in increasing the risk of its infection [4]. Treatment measures developed over the years include sialogogues, massage of the gland as well as administration of antibiotics [3]. Cementoossifying fibroma is also one of the benign tumours of the face affecting mostly the jaw bone and originating from the periodontal ligament. It is an encapsulated neoplasm with fibrous tissue and varied calcified tissue [5]. It has its common site of occurrence on the mandibular premolarmolar region, with males as its prevalent gender of occurrence [6]. The usual microscopy shows a benign lesion composed of cellular fibrous connective tissue stroma with islands of bone trabeculae (predominantly) and ossicles. The treatment procedure involved in this disease condition is mostly surgical excision with reconstruction of the after structure [7]. Bone cyst, a pseudo-cystic lesion involves the replacement of normal bone with blood-filled sinuses as well as cavernous spaces. It is benign in nature with its commonest site of occurrence being the jaws. Surgery is the main form of treatment, same as in cement-ossifying fibroma [8]. Burkitt Lymphoma an aggressive B-cell non-Hodgkin Lymphoma, is an example of malignant facial tumour caused by the translocation of MYC on the chromosome 8 which affects the supraclavicular lymph nodes which are usually the early signs of this disease [9]. Malaria and Epstein-Barr virus have been shown to influence the level of susceptibility to this disease condition. The presenting symptoms associated this condition include facial swelling, hepatosplenomegaly, intussusceptions etc [10]. Chemotherapy has proven to be an effective measure in the treatment of this condition [11]. Ameloblastoma is a benign form of facial tumor of odontogenic origin affecting the maxillofacial skeleton with its predilection been the mandibular molar region. It constitute $1-3 \%$ of all jaw tumors and cysts with race being a risk factor to its prevalence level. The blacks have a higher prevalence than the whites alongside age and gender [12]. It can occur at any age. However, a study has shown younger age group within the ages of 15-25 to have higher prevalence as well as males over their female counterparts [13]. In another study, it was observed age was not a factor in the susceptibility of ameloblastoma with its commonest sign being swelling as well as pain, rapid growth [14]. The histology generally shows a benign lesion composed of islands, strands and sheets of odontogenic epithelium with outer palisaded ameloblast-like cells and inner stellate cells. Surgical resection within 1 to $2 \mathrm{~cm}$ of normal bone and reconstruction is the main modality of treatment of ameloblastoma.

Squamous cell carcinoma is the 2nd in the rank of cutaneous malignancy after chronic ulcers among Nigerians as well as other part of Africa. It is also documented to be the commonest dermatological malignancy among Black Americans with its commonest occurrence in the oral cavity [15]. Certain risk factors have been associated to the cause of this disease. Sun exposure is a major etiological factor. Both sun exposure and genetics influence the susceptibility of patients to this disease condition [16]. Treatment method of squamous cell carcinoma includes surgical excision and or radiotherapy/chemotherapy. Other treatment methods have been developed over the years to help curb this condition. They include proper wound care, and human immunodeficiency virus control [17]. Keloid a fibro proliferative disorder of the skin developed as a result of abnormal healing of damage skin surfaces. Genetics and systemic factors such as pregnancy, hypertension and local factors are contributory factors to the development of this disease condition [18]. Other histopathological diagnosis patterns of facial tumors discovered include bony harmatoma, lymphoma, dentigerous cyst, sacrcoma, bony exostoses, fibro-epithelial hyperplasia, fibrous dysplasia, granuloma, haemangioma, hemorrhagic cyst, monomorphic adenoma, and myoepithelioma. The Centre For this study, Teem Dental Centre is a well-equipped private outfit that has been in operation for 17 years. With well-trained personnels it handles general dental treatment with specialist oral maxillofacial cases being treated on an out-patient and in-patient basis. The Centre also act as a referral for maxillofacial cases from distant and close private dental clinics.

\section{Methodology}

In course of this study, a retrospective cross-sectional survey design alongside purposive sampling technique was adopted for the purpose of data collection. Data obtained were from the medical records of patients with facial tumours seen between 2009 and 2019, at Teem Dental Centre, a private outfit with specialist oral maxillofacial services in Delta State, Nigeria. The data obtained included patient's age, gender, site of lesion, clinical features and the histopathology report of the tumours seen either from incisional or excisional biopsies. Statistical analysis was done via Statistical Package for Social sciences (SPSS) version 23.0. Results were presented using simple percentage frequency distribution as the descriptive statistics and Chi-square test of association was used for the inferential statistics. Significance was accepted at a probability value less than 0.05 . 


\section{Results}

Table 1 shows the distribution of facial tumour diagnosis with 62 different tumour samples of which Ameloblastoma shows the highest frequency of $9(14.5 \%)$. This was closely followed by cement-ossifying fibroma and acute on chronic suppurative inflammation with frequencies $6(9.7 \%)$ respectively. The least prevalent histological diagnoses were bone cyst, bony harmatoma, chronic sialadenitis, exostoses, fibroepithelial hyperplasia, fibrous dysplasia, hemorrhagic cyst, keliod, non Hodgkins lymphoma, odontogenic cyst, orofacial granulomatosis, polyp, pseudotumour with frequencies of $1(1.6 \%)$ respectively.

\begin{tabular}{|c|c|}
\hline Facial Tumour & Frequency (\%) \\
\hline $\begin{array}{c}\text { Acute and chronic supprative } \\
\text { inflammation }\end{array}$ & $6(9.7)$ \\
\hline Adenoid cystic carcinoma & $5(8.1)$ \\
\hline Ameloblastoma & $9(14.5)$ \\
\hline Bone cyst & $1(1.6)$ \\
\hline Bony harmatoma & $1(1.6)$ \\
\hline Burkitts lymphoma & $1(1.6)$ \\
\hline Cemento- ossifying fibroma & $6(9.7)$ \\
\hline Chronic sialadenitis & $1(1.6)$ \\
\hline Cutaneous lymphoma & $2(3.2)$ \\
\hline Dentigerous cyst & $4(6.5)$ \\
\hline Exostoses & $1(1.6)$ \\
\hline Fibro epithelial hyperplasia & $1(1.6)$ \\
\hline Fibrous dysplasia & $1(1.6)$ \\
\hline Granuloma/ haemangioma & $3(4.8)$ \\
\hline Hemorrhagic cyst & $1(1.6)$ \\
\hline Keloid & $1(1.6)$ \\
\hline Monomorphic adenoma & $4(6.5)$ \\
\hline Myoepithelioma & $2(3.2)$ \\
\hline Non hodgkins lymphoma & $1(1.6)$ \\
\hline Odontogenic cyst & $1(1.6)$ \\
\hline Orofacial granulomatosis & $1(1.6)$ \\
\hline Polyp & $1(1.6)$ \\
\hline Pseudotumour & $1(1.6)$ \\
\hline Sarcoma & $2(3.2)$ \\
\hline Solitary fibrous tumour & $2(3.2)$ \\
\hline Squamous cell carcinoma & $3(4.8)$ \\
\hline Total & $62(100.0)$ \\
\hline
\end{tabular}

Table 1: Distribution of Facial Tumour according to histological Diagnosis.
Table 2 depicts the gender distribution of facial tumour with the female patients having a higher prevalence rate of $35(56.5 \%)$ than their male counterparts which had a frequency of $27(43.5 \%)$.

\begin{tabular}{|c|c|}
\hline Gender & Frequency (\%) \\
\hline Male & $27(43.5)$ \\
\hline Female & $35(56.5)$ \\
\hline Total & $62(100)$ \\
\hline
\end{tabular}

Table 2: Distribution of Facial Tumour according to Gender.

Table 3 shows patients with the ages of 21-25 years having the highest frequency of $9(14.5 \%)$.Those within the age groups of 51-55 years and 61-65 years had a frequency of $7(11.3 \%)$ each. The age range of $76-80$ years having the least prevalent rate of $1(1.6 \%)$. Table 4 shows the test of association between age groups and facial tumour histological diagnosis which indicates no statistical significance; $p \geq 0.05$ $(\mathrm{p}=0.601)$. Table 5 depicts the test of association between facial tumour diagnosis and gender which shows a case of statistical significance with the p-value $=0.01$.

\begin{tabular}{|c|c|}
\hline Age groups & Frequency (\%) \\
\hline 5-10 years & $5(8.1)$ \\
\hline 11-15years & $6(9.7)$ \\
\hline 16-20years & $3(4.8)$ \\
\hline $21-25$ years & $9(14.5)$ \\
\hline 26-30years & $2(3.2)$ \\
\hline 31-35year & $6(9.7)$ \\
\hline 36-40years & $2(3.2)$ \\
\hline 41-45years & $2(3.2)$ \\
\hline 46-50years & $2(3.2)$ \\
\hline 51-55years & $7(11.3)$ \\
\hline 56-60years & $6(9.7)$ \\
\hline 61-65years & $7(11.3)$ \\
\hline 66-70years & $2(3.2)$ \\
\hline $71-75 y e a r s$ & $2(3.2)$ \\
\hline $76-80$ years & $1(1.6)$ \\
\hline Total & $62(100)$ \\
\hline
\end{tabular}

Table 3: Distribution of Facial Tumour according to Age groups. 


\begin{tabular}{|c|c|c|c|c|c|c|c|c|c|c|c|c|c|c|c|c|c|}
\hline \multirow[b]{2}{*}{ Diagnosis } & \multicolumn{15}{|c|}{ Age groups } & \multirow[b]{2}{*}{$\begin{array}{c}\text { Chi- } \\
\text { square }\end{array}$} & \multirow[b]{2}{*}{$\begin{array}{c}\mathrm{p}- \\
\text { value }\end{array}$} \\
\hline & $\begin{array}{l}05- \\
\text { Oct }\end{array}$ & $\begin{array}{l}15- \\
\text { Nov }\end{array}$ & $16-20$ & $21-25$ & $26-30$ & 31-35 & $36-40$ & $41-45$ & $546-50$ & $051-55$ & \begin{tabular}{l|l|}
5 & $56-60$
\end{tabular} & $61-656$ & $66-70$ & $71-75$ & $\begin{array}{c}76- \\
80\end{array}$ & & \\
\hline $\begin{array}{l}\text { Acute And Chronic } \\
\text { Supprative } \\
\text { Inflammation }\end{array}$ & - & - & - & 2 & - & - & - & - & - & - & 1 & 3 & - & - & - & & \\
\hline $\begin{array}{l}\text { Adenoid Cystic } \\
\text { Carcinoma }\end{array}$ & - & - & - & 1 & - & - & 1 & - & - & 2 & - & - & - & - & 1 & & \\
\hline Ameloblastoma & 1 & 2 & - & 1 & 1 & 2 & - & - & 1 & 1 & - & - & - & - & - & & \\
\hline Bone Cyst & - & - & - & - & - & - & - & - & - & - & 1 & - & - & - & - & & \\
\hline Bony Harmatoma & - & - & - & - & - & 1 & - & - & - & - & - & - & - & - & - & & \\
\hline Burkitts Lymphoma & - & 1 & - & - & - & - & - & - & - & - & - & - & - & - & - & & \\
\hline $\begin{array}{c}\text { Cemento- Ossifying } \\
\text { Fibroma } \\
\end{array}$ & 1 & - & 1 & - & - & - & - & - & 1 & - & 2 & - & - & 1 & - & & \\
\hline Chronic Sialadenitis & - & - & - & - & - & - & 1 & - & - & - & - & - & - & - & - & & \\
\hline Cutaneous Lymphoma & - & - & 1 & - & - & - & - & - & - & - & - & - & 1 & - & - & & \\
\hline Dentigenous Cyst & - & 1 & - & 1 & - & - & - & 1 & - & - & - & 1 & - & - & - & & \\
\hline Exostoses & - & - & - & - & - & - & - & - & - & - & - & 1 & - & - & - & & \\
\hline $\begin{array}{c}\text { Fibro Epithelial } \\
\text { Hyperplasia }\end{array}$ & - & - & - & - & - & - & - & - & - & - & - & 1 & - & - & - & & \\
\hline Fibrous Dysplasia & - & - & - & - & - & - & - & 1 & - & - & - & - & - & - & - & & \\
\hline $\begin{array}{c}\text { Granuloma/ } \\
\text { Haemangioma }\end{array}$ & - & - & - & - & - & - & - & - & - & 1 & 1 & 1 & - & - & - & 342.6 & 0.601 \\
\hline Hemorrhagic Cyst & - & - & - & - & - & - & 1 & - & - & - & - & - & - & - & - & & \\
\hline Keloid & - & - & - & 1 & - & - & - & - & - & - & - & - & - & - & - & & \\
\hline $\begin{array}{c}\text { Monomorphic } \\
\text { Adenoma }\end{array}$ & - & 1 & 1 & - & - & 2 & - & - & - & - & - & - & - & - & - & & \\
\hline Myoepithelioma & 1 & - & - & - & - & - & - & - & - & - & 1 & - & - & - & - & & \\
\hline $\begin{array}{l}\text { Non Hodgkins } \\
\text { Lymphoma }\end{array}$ & - & - & - & - & - & - & - & - & - & 1 & - & - & - & - & - & & \\
\hline Odontogenic Cyst & - & 1 & - & - & - & - & - & - & - & - & - & - & - & - & - & & \\
\hline $\begin{array}{c}\text { Orofacial } \\
\text { granulomatosis }\end{array}$ & - & - & - & 1 & - & - & - & - & - & - & - & - & - & - & - & & \\
\hline Polyp & - & - & - & - & 1 & - & - & - & - & - & - & - & - & - & - & & \\
\hline Pseudo Tumour & - & - & - & 1 & - & - & - & - & - & - & - & - & - & - & - & & \\
\hline Sarcoma & 1 & - & - & 1 & - & - & - & - & - & - & - & - & - & - & - & & \\
\hline $\begin{array}{l}\text { Solitary Fibrous } \\
\text { Tumour }\end{array}$ & 1 & - & - & - & - & 1 & - & - & - & - & - & - & - & - & - & & \\
\hline $\begin{array}{l}\text { Squamous Cell } \\
\text { Carcinoma }\end{array}$ & - & - & - & - & - & - & 1 & - & - & 2 & - & - & - & - & - & & \\
\hline Total & 5 & 6 & 3 & 9 & 2 & 6 & 4 & 2 & 2 & 7 & 6 & 7 & 1 & 1 & 1 & & \\
\hline
\end{tabular}

Table 4: Chi-square test of association between age groups and facial tumour diagnosis. 


\begin{tabular}{|c|c|c|c|c|}
\hline \multirow{2}{*}{ Diagnosis } & \multicolumn{2}{|c|}{ Gender } & \multirow[b]{2}{*}{ Chi-square } & \multirow[b]{2}{*}{ p-value } \\
\hline & Male & Female & & \\
\hline Acute and Chronic Supprative Inflammation & - & 6 & \multirow{27}{*}{52.283} & \multirow{27}{*}{0.001} \\
\hline Adenoid Cystic Carcinoma & - & 5 & & \\
\hline Ameloblastoma & 2 & 7 & & \\
\hline Bone Cyst & - & 1 & & \\
\hline Bony Harmatoma & - & 1 & & \\
\hline Burkitts Lymphoma & - & 1 & & \\
\hline Cemento- Ossifying Fibroma & 1 & 5 & & \\
\hline Chronic Sialadenitis & - & 1 & & \\
\hline Cutaneous Lymphoma & - & 2 & & \\
\hline Dentigenous Cyst & - & 4 & & \\
\hline Exostoses & - & 1 & & \\
\hline Fibro Epithelial Hyperplasia & - & 1 & & \\
\hline Fibrous Dysplasia & 1 & - & & \\
\hline Granuloma/ Haemangioma & 3 & - & & \\
\hline Hemorrhagic Cyst & 1 & - & & \\
\hline Keloid & 1 & - & & \\
\hline Monomorphic Adenoma & 4 & - & & \\
\hline Myoepithelioma & 2 & - & & \\
\hline Non Hodgkins Lymphoma & 1 & - & & \\
\hline Odontogenic Cyst & 1 & - & & \\
\hline Orofacialgranulomatosis & 1 & - & & \\
\hline Polyp & 1 & - & & \\
\hline Pseudo Tumour & 1 & - & & \\
\hline Sarcoma & 2 & - & & \\
\hline Solitary Fibrous Tumour & 2 & - & & \\
\hline Squamous Cell Carcinoma & 3 & - & & \\
\hline Total & 27 & 35 & & \\
\hline
\end{tabular}

Table 5: Chi-square test of association between gender and diagnosis of facial tumour.

\section{Discussion}

Facial tumours, like all tumors have certain factors which influence the susceptibility of an individual to this disease condition. They include viral infections like Human Immunodeficiency/Acquired Immunodeficiency Syndrome and Epsten-Barr virus. Genetic factors such as the translocation of MYC on chromosome 8 influences the level of prevalence of this disease condition [2]. This condition has been shown to involve the abnormal or irregular production of cells around the face including the mouth, nose, eyes as well as the skin layer covering the face [1]. Studies have also shown the occurrence of facial tumor to be higher in developing countries than underdeveloped countries [19]. The results obtained from this study showed ameloblastoma to be the most prevalent facial tumor histological diagnosis with a frequency of $9(14.5 \%)$. This was in coherence with studies [20-22] conducted which showed ameloblastoma ranking the highest among all observed facial tumour diagnosis, but at variance with the results obtained from another study El Gehani R, et al. [23], which showed odontogenic cyst to have a higher prevalence than ameloblastoma. It also showed female predilection over males for ameloblastoma. This was supported by the findings of Adekeye EO and Odukoya 0 $[24,25]$ but at variance with those obtained by Tawfik MA, et al. [26] which showed a male predilection of ameloblastoma. 
Cemento-ossifying fibroma, another facial tumour diagnosis with an incidence level of $6(9.7 \%)$ had the next highest frequency with more occurrence in patients above 46 years. This is in agreement with the study Abdulbaset D, et al. [27] which produced similar results. Another study Sanchis JM [28] obtained slightly different results which showed patients within the age groups of 30-40 years having a higher prevalence of cement-ossifying fibroma. The results also indicated females having higher prevalence than males in histological diagnosis of cement-ossifying fibroma. This showed similarity with a study Eversole LR, et al. [29] which showed a female predilection of cement-ossifying fibroma. Results from this study showed subjects within the age range of $21-25$ years $9(14.5 \%)$ having a higher frequency than those of other age groups. This is in conformity with results obtained from a study conducted by Guerrisi M [30], but in disparity with results of a study conducted by Arotiba GT [21] which showed patients with the ages of 12-15 years having a higher incidence of tumours affecting the face.

\section{Conclusion}

Facial tumour is an abnormal outgrowth of the cellular constituent of the face which has been shown to have higher occurrences in females $35(56.5 \%)$ than males $27(43.5 \%)$, with its commonest histological diagnosis being ameloblastoma with a distribution of $9(14.5 \%)$.

Acknowledgment: The immense contribution of the General and Oral pathologists is greatly acknowledged and appreciated.

\section{References}

1. Diepgen TL, Mahler V (2002) The epidemiology of skin cancer. Br J Dermatol 61: 1-6.

2. Mandong BM, Orkar KS, Sule AZ, Dakum NL (2000) Malignant skin tumours in Jos University Teaching Hospital, Jos, Nigeria (hospital-based study). Nigerian Journal of Surgical Research 3(1): 29-33.

3. Sharer WG, Hine MK, Levy BM (1983) A Textbook of Oral Pathology. $4^{\text {th }}$ (Edn.), Philadelphia: WB Saunders Company.

4. McQuone SJ (1999) Acute viral and bacterial infections of the salivary glands. Otolaryngol Clin North Am 32(5): 793-811.

5. Ram R, Singhal A, Singhal P (2012) Cemento-ossifying fibroma. Contemp Clin Dent 3(1): 83-85.

6. Ong AH, Siar CH (1998) Cemento-ossifying fibroma with mandibular fracture. Case report in a young patient. Aust Dent J 43(4): 229-233.
7. Kamadjaja DB (2009) Cemento-ossifying fibroma of the jaw. Dent J 42(4): 164-171.

8. Svenson B, Isacsson G (1993) Benign osteoblastoma associated with an aneurismal bone cyst of the mandibular ramus and condyle. Oral Surg Oral Med Oral Pathol 76(4): 433-436.

9. Hecht JL, Aster JC (2000) Molecular biology of Burkitt's lymphoma. J Clin Oncol 18(21): 3707-3721.

10. Magrath I (2012) Epidemiology: clues to the pathogenesis of Burkitt lymphoma. Br J Haematol 156(6): 744-756.

11. Kitterman CK, Marante A, Berry AC (2017) Burkitt lymphoma. Consultant 360.

12. Simko EJ, Brannon RB, Eibling DE (1998) Ameloblastoma of the mandible. Head Neck 20(7): 654-659.

13. Kim SG, Jang HS (2001) Ameloblastoma: a clinical, radiographic, and histopathologic analysis of 71 cases. Oral Surg Oral Med Oral Pathol Oral RadiolEndod 91(6): 649-653.

14. Cizmecy O, Aslan A, Onel D, Demiryont M (2004) Ameloblastoma carcinoma ex ameloblastoma of the mandible: case report. Otolaryngol Head Neck Surg 130(5): 633-634.

15. Marks R (1995) An overview of skin cancer: Incidence and causation. Cancer 75(2): 607-612.

16. Kricker A, Amstrong BK, English DR (1994) Sun exposure and non-melanocytic skin cancer. Cancer Causes Control 5: 367-392.

17. Adeyi O, Banjo AA (1996) Malignant tumours of the skin: a six year review of histologically diagnosed cases (1990-1995). Nigerian Quarterly Journal of Hospital Medicine 8(2): 99-102.

18. Bran GM, Goessler UR, Hormann K, Riedel F, Sadick H (2009) Keloids: current concepts of pathogenesis (review). Int J Mol Med 24(3): 283-293.

19. Urbach F (1991) Incidence of nonmelanoma skin cancer. Dermatol Clin 9(4): 751-755.

20. Arotiba GT, Ladeinde AL, Arotiba JT, Ajike SO, Ugboko VI, et al. (2005) Ameloblastoma in Nigerian children and adolescents: a review of 79 cases. J Oral Maxillofac Surg 63(6): 747-751.

21. Arotiba GT (1996) A study of oro-facial tumours in Nigerian children. J Oral Maxillof Surg 54(1): 34-38.

22. Ladeinde AL, Ajayi OF, Ogunlewe MO, Adeyemo WL, 


\section{Open Access Journal of Dental Sciences}

Arotiba GT, et al. (2005) Odontogenic tumors: A review of 319 cases in a Nigerian teaching hospital. Oral Surg Oral Med Oral Pathol Oral Radiol Endod 99(2): 191-195.

23. El Gehani R, Krishnan B, Orafi H (2008) The prevalence of inflammatory and developmental odontogenic cysts in a Libyan population. Libyan J Med 3(2): 75-77.

24. Adekeye EO (1980) Ameloblastoma of the jaws. A Survey of 109 Nigerian patients. J Oral Surg 38(1): 36-41.

25. Odukoya O (1995) Odontogenic tumors: analysis of 289 Nigerian cases. J Oral pathol Med 24: 454-457.

26. Tawfik MA, Zyadia MM (2010) Odontogenic tumors in Dakahlia, Egypt: analysis of 82 cases. Oral Surg Oral Med Oral Pathol Oral Radiol Endod 109(2): 67-73.
27. Dalghous A, Alkhabuli OJ (2007) Cemento-ossifying fibroma occurring in an elderly patient. A case report and a review of literature, Libyan J Med 2(2): 95-98.

28. Sanchis JM, Peñarrocha M, Balaguer JM, Camacho F (2004) Fibroma cemento-osificante mandibular: Presentación de dos casos y revisión de la literatura. Med Oral 9: 69-73.

29. Eversole LR, Leider AS, Nelson K (1985) Ossifying fibroma: A clinicopathologic study of sixty-four cases. Oral Surg Oral Med Oral Pathol 60(5): 505-511.

30. Guerrisi M, Piloni MJ, Keszler A (2007) Odontogenic tumors in children and adolescents. A 15 year retrospective study in Argentina. Med Oral Patol Oral Cir Bucal 12(3): 180-185. 